e-ISSN; 2528-0325 ISSN; 2528-0317 Tasharruf : Vol. 2 No. 2. Desember Journal Economic and Business Of Islam 2017

\title{
Influence Student Attitudes toward Learning Outcomes Enterprise Class X in SMK 4 Makassar Sudarmi
}

Sudarmi978@gmail.com

\section{Sekolah Tinggi Ilmu Manajeme Lasharan Jaya Makassar}

Abstrak

This study was conducted to answer the question "whether there is influence entrepreneurial attitudes toward learning outcomes tenth grade students in SMK 4 Makassar". Thus, this study aims to determine the effect of attitudes towards learning outcomes entrepreneurial class X in SMK 4 Makassar. To that end, the results of this study would be useful: (1) Improve learning outcomes by improving students' attitude towards entrepreneurship subjects; (2) as input for all parties involved in the world of education, particularly entrepreneurial subject teachers in improving student learning outcomes; and (3) as a comparison to other researchers for further research purposes.

This study is a verification that is correlational, meaning that the data and facts collected from the field is not manipulated, just to test the correctness of the theory as well as to validate the hypothesis, with a total population of 38 people. Data collection techniques used, namely, observation and questionnaires. Analysis of the data used are; Descriptive statistical analysis and statistical analysis infrensial. In analyzing the data using SPSS 20 software.

The results showed; partially student attitudes and no significant positive effect on learning outcomes of entrepreneurship students in SMK 4 Makassar. At the significant level $\alpha=0.05$ with a regression equation $Y=65591+0.271 X$ and the coefficient of determination ( $R 2)$ of 0.085 percent, which means about 8.5 percent of entrepreneurial learning outcomes of students affected by the attitudes of the students, while the remaining 91.5 per cent are affected by other factors not considered in this study. Student attitudes insignificant variable $(X)$ to the entrepreneurial student learning outcomes $(Y)$ can be caused by several factors, one of them is the attitude of students is less enthusiastic in participating in 
entrepreneurship subjects. This is evident from the lack of attention to students when learning activities take place, this is due to the students' attention is divided for things that have nothing to do with the lessons that certainly can interfere with concentration and attention of students in participating subjects of entrepreneurship.

\section{Keywords: Attitudes and Learning Outcomes}

\section{PENDAHULUAN}

Kemajuan dan perkembangan suatu bangsa sangatlah ditentukan oleh kualitas pendidikan, karena pendidikan merupakan sarana untuk mencerdaskan kehidupan bangsa. Dimana pendidikan diharapkan dapat mengubah sikap serta tingkah laku seseorang dengan jalan menambah pengetahuan dan keterampilan. Pendidikan juga bisa merupakan dijadikan tolak ukur kemajuan dan perkembangan suatu bangsa, yang artinya maju dan mundurnya, berkembang dan melemahnya suatu bangsa didukung oleh kualitas pendidikan. Dalam perkembangan dan kemajuan jaman sekarang ini, semua bangsa di dunia menyiapkan diri untuk menghadapi persaingan yang sangat pesat yang ditimbulkan oleh Ilmu Pengetahuan dan Teknologi (IPTEK) yang berkembang sangat cepat disegala bidang.

Sehubungan dengan kemajuan dan perkembangan Ilmu Pengetahuan dan Teknologi yang terjadi saat ini, dunia pendidikan yang menjadi tolak ukur suatu bangsa, jadi tidak mengherankan jika suatu bangsa menempatkan pendidikan sebagai salah satu strategis pembangunan dalam menyiapkan sumber daya manusia (SDM) yang berkualitas dan dapat berkompetensi di bidangnya masing-masing.

Dunia pendidikan benar-benar mendapatkan perhatian khusus dari pemerintah. Pemerintah kiranya dapat melakukan pembenahan dan perbaikan pada sistem pendidikan sekarang ini, karena peran pendidikan sangatlah dibutuhkan untuk kemajuan bangsa.

Salah satu tujuan pendidikan nasional yang tercantum dalam UndangUndang RI No.20 Tahun 2003 tentang SISDIKNAS (Sistem Pendidikan Nasional) pasal 3 berbunyi, "Pendidikan nasional berfungsi untuk mengembangkan dan 
membentuk kehidupan bangsa yang tujuannya untuk mengembangkan dan memajukan potensi peserta didik agar menajdi manusia yang beriman dan bertakwa kepada Tuhan Yang Maha Esa, berakhlak mulia, sehat, berilmu, cakap, kreatif, mandiri, serta menjadi warga Negara yang demokratis dan bertanggung jawab”.

Untuk mewujudkan pendidikan nasional tersebut diperlukan adanya lembaga pendidikan, baik formal maupun non formal. Sekolah merupakan lembaga pendidikan formal yang mempunyai pengaruh cukup besar terhadap perkembangan dan pembentukan kepribadian siswa. Karena lembaga inilah para siswa menerima pengetahuan yang bertujuan untuk mendewasakan dirinya. Selain itu, lewat lembaga ini juga siswa belajar menunjukkan adanya perubahan yang sifatnya positif sehingga pada tahap akhir akan didapat keterampilan, kecakapan, dan pengetahuan baru. Salah satu bentuk pendidikan formal tersebut adalah Sekolah Menengah Kejuruan (SMK).

Dalam suatu lembaga pendidikan, hasil belajar merupakan indikator yang penting untuk mengukur keberhasilan proses belajar mengajar. Akan tetapi tidak bisa dipungkiri bahwa tinggi rendahnya hasil belajar siswa banyak dipengaruhi oleh berbagai faktor, baik faktor internal maupun faktor eksternal. Faktor internal yaitu faktor yang berasal dari dalam diri siswa mencakup kesehatan jasmani maupun rohani, intelegensi dan bakat siswa, minat dan motivasi siswa, cara belajar serta sikap siswa. Sedangkan faktor eksternal yaitu faktor yang berasal dari luar diri siswa mencakup : Keluarga, sekolah, masyarakat, dan lingkungan. Dalam penelitian ini penulis tertarik untuk meneliti lebih lanjut mengenai salah satu faktor internal yakni mengenai sikap siswa.

Slameto (2003:188) menyatakan bahwa sikap juga merupakan salah satu faktor yang mempengaruhi proses pembelajaran dan berpengaruh terhadap hasil belajar yang akan diperoleh siswa. Setiap siswa memiliki karakteristik yang berbeda, begitu pula dengan kecenderungan sikap yang dimilikinya. Aunurrahman (2008:37) menjelaskan bahwa aktivitas belajar siswa banyak ditentukan oleh sikap siswa ketika akan memulai kegiatan belajar. Bilamana ketika akan memulai kegiatan belajar, siswa memiliki sikap menerima (positif) atau ada kesediaan emosional untuk belajar, 
maka siswa akan cenderung untuk berusaha terlibat dalam kegiatan belajar dengan baik. Namun bila yang muncul adalah sikap menolak (negatif) sebelum belajar atau ketika akan memulai pembelajaran, maka siswa cenderung kurang memperhatikan/mengikuti kegiatan belajar. Sikap siswa ini terlihat pada saat mengikuti pelajaran atau sebaliknya bersikap acuh terhadap aktivitas belajar.

Berdasarkan observasi awal yang dilakukan di SMK Negeri 4 Makassar diperoleh data bahwa masih terdapat siswa yang hasil belajar kewirausahaannya di bawah standar ketuntasan yang telah ditentukan. Dimana Batas Kriteria Ketuntasan Minimal (KKM) untuk mata pelajaran kewirausahaan adalah 72. Hal ini terlihat dari 38 orang siswa masih ada sekitar 19 siswa (50\%) yang mengikuti remedial (Informasi dari guru bidang studi kewirausahaan).

Berdasarkan realitas yang ada, tidak semua siswa menunjukkan sikap positif dalam belajar dan kadang menjadi hambatan yang serius bagi siswa dalam mencapai hasil belajar yang memuaskan. Sikap siswa yang negatif yang sering muncul adalah beberapa siswa yang cenderung malas untuk belajar kewirausahaan, siswa kurang memperhatikan guru saat sedang menerangkan pelajaran bahkan ada yang mengobrol dengan teman sebangku. Sikap yang tidak seharusnya dilakukan siswa pada saat proses belajar mengajar berlangsung. Hal ini tentunya dapat mengganggu proses belajar mengajar.

Sikap siswa yang positif terhadap guru ataupun mata pelajaran merupakan pertanda awal yang baik bagi proses belajar siswa dan hasil belajar yang dicapai siswapun akan baik. Sebaliknya jika sikap negatif siswa terhadap guru ataupun mata pelajaran yang disajikan akan menimbulkan kesulitan belajar bagi siswa tersebut, maka hasil belajar yang dicapai siswa pun akan rendah. (Islamuddin, 2011:185-186).

\section{METODE PENELITIAN}

\section{A. Variabel dan Desain Penelitian}

\section{Variabel Penelitian}

Variabel penelitian adalah: 
a) Variabel bebas (independent variable) dalam penelitian ini adalah Sikap siswa pada pelajaran kewirausahaan $(\mathrm{X})$

b) Variabel terikat (dependent variable) dalam penelitian ini adalah Hasil Belajar kewirausahaan Siswa (Y).

\section{Disain Penelitian}

Disain penelitian merupakan rancangan atau cara untuk melaksanakan penelitian dalam rangka memperoleh data yang dibutuhkan. Penelitian ini merupakan penelitian expost facto yang bertujuan untuk mengetahui pengaruh variabel bebas terhadap variabel terikat. Pendekatan yang digunakan adalah pendekatan kuantitatif yang artinya semua informasi atau data yang diperoleh diwujudkan dengan angka dan analisis yang digunakan adalah analisis statistik.

Untuk lebih jelasnya, maka desain penelitian dapat digambarkan sebagai berikut :

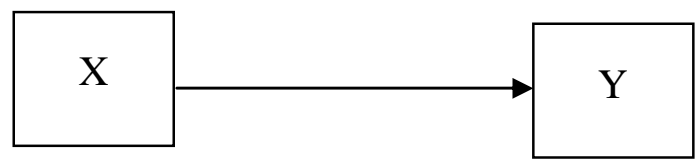

Gambar 1.

Hubungan antara variabel $\mathrm{X}$ dengan variabel $\mathrm{Y}$

Keterangan:

$\mathrm{X} \quad$ : Sikap siswa pada pelajaran kewirausahaan

Y : Hasil belajar kewirausahaan siswa

\section{B. Defenisi Operasional dan Pengukuran Variabel}

\section{Defenisi Operasional Variabel}

Defenisi Operasional dari variabel-variabel diatas adalah sebagai berikut:

\section{a. Sikap siswa pada pelajaran kewirausahaan $(\mathrm{X})$}

Sikap siswa yang dimaksud dalam penelitian ini adalah kecenderungan siswa untuk berperilaku pada saat pelajaran kewirausahaan berlangsung. Variabel sikap siswa ini diungkap dengan menggunakan skala sikap yang mengacu pada indikator yakni (1) ketekunan belajar mencakup kesungguhan siswa dalam mengikuti pelajaran dan tekun dalam mengerjakan tugas; (2) rajin dalam belajar mencakup giat belajar 
untuk mendapatkan hasil belajar yang bagus dan tidak mudah putus asa; (3) kedisiplinan belajar mencakup patuh dan taat terhadap kegiatan belajar di sekolah, perhatian terhadap kegiatan pembelajaran, dan persiapan belajar; (4) tanggung jawab.mencakup menyelesaikan tugas pada waktunya, mengutamakan usaha sendiri daripada bantuan orang lain, dan dapat bekerjasama secara berkelompok.

\section{b. Hasil belajar kewirausahaan (Y)}

Hasil belajar adalah tingkat penguasaan dan pemahaman siswa pada mata pelajaran kewirausahaan yang ditunjukkan dengan nilai tes yang diberikan oleh guru mata pelajaran. Skor tentang hasil belajar kewirausahaan ini berdasarkan nilai ulangan harian yang diperoleh siswa kelas $\mathrm{X}$ dan skor yang yang dicapai oleh siswa setelah diberikan instrumen berupa skala penilaian angket hasil belajar yang meliputi: (1) Kognitif: Pengamatan, Ingatan, Pemahaman, Penerapan, Analisis, Sintesis. (2) Afektif: Penerimaan, Sambutan, Apresiasi, Internalisasi, Karakterisasi. (3) Psikomotor, Keterampilan bergerak dan bertindak, Kecakapan ekspresi verbal dan non verbal.

\section{Pengukuran Variabel}

Pengukuran variabel ini menggunakan skala ordinal dengan memberi skor pada tiap-tiap pertanyaan. untuk kedua variabel. Adapun daftar pertanyaan yang disusun telah ditetapkan oleh peneliti dengan menggunakan skala Likert. Setiap jawaban dari pertanyaan akan diberikan skor numerik (angka) menurut Sugiyono (2012:136) sesuai hasil penelitian yang diperoleh.

1) Setuju/selalu/sangat positif diberi skor 5

2) Setuju/sering/positif/ diberi skor 4

3) Ragu-ragu/kadang-kadang/netral diberi skor 3

4) Tidak setuju/hampir tidak pernah/ negative diberi skor 2 
ISSN; 2528-0317 Tasharruf : Journal Economic Vol. 2 No. 2 Desember 2017 and Business Of Islam

5) Sangat tidak setuju/tidak pernah diberikan skor

1

\section{Populasi penelitian}

\section{Populasi}

Populasi dalam penelitian ini adalah seluruh siswa kelas X di SMK Negeri 4 Makassar tahun pelajaran 2016/2017, berjumlah 1.017 Lebih jelasnya dapat dilihat pada tabel 1 berikut ini.

Tabel 1. Jumlah Siswa Kelas X di SMK Negeri 4 Makassar

\begin{tabular}{ccc}
\hline No. & Kelas/Jurusan & Jumlah \\
\hline X TKJ 1 & 36 \\
X TKJ 2 & 37 \\
\hline X UPW 1 & 36 \\
\hline X UPW 2 & 37 \\
\hline X JB 1 & 36 \\
\hline X JB 2 & 38 \\
\hline X JB 3 & 38 \\
\hline X TGB & 36 \\
\hline X PM 1 & 35 \\
\hline X PM 2 & 39 \\
\hline X PM 3 & 39 \\
\hline X AP 1 & 37 \\
\hline X AP 2 & 38 \\
\hline X AP 3 & 38 \\
\hline X AP 4 & 39 \\
\hline X AK 1 & 37 \\
\hline X AK 2 & 38 \\
\hline X AK 3 & 38 \\
\hline X AK 4 & 39 \\
\hline Jumlah & 1.017 \\
\hline
\end{tabular}

Sumber: Tata Usaha SMK Negeri 4 Makassar, 2016

Mengingat jumlah populasi yang begitu besar, maka peneliti menetapkan populasi melalui keterwakilan setiap jurusan.

Lebih jelasnya dapat dilihat pada tabel 2 berikut.

Tabel 2. Jumlah Populasi Berdasarkan Keterwakilan Setiap Jurusan

\begin{tabular}{ccl}
\hline No. & Kelas/Jurusan & Jumlah \\
\hline X TKJ 1 & 36 \\
\hline & 7 &
\end{tabular}


ISSN; 2528-0317 Tasharruf : Journal Economic Vol. 2 No. 2 Desember 2017 and Business Of Islam

\begin{tabular}{rr}
\hline X UPW 1 & 36 \\
\hline X JB 1 & 36 \\
\hline X TGB & 36 \\
\hline X PM 1 & 35 \\
\hline X AP 1 & 37 \\
\hline X AK 1 & 37 \\
\hline Jumlah & 253 \\
\hline
\end{tabular}

Sumber: Populasi setelah diolah, 2016

\section{Sampel}

Penarikan sampel sebesar 15 persen mengacu dari pendapat Arikunto (2000:45) bahwa, “.... jika subjek lebih dari 100 maka dapat diambil 5-10\%, 20-30\% atau lebih....".

Berdasarkan pendapat tersebut, maka jumlah sampel yang diambil adalah 15 persen dari 253 yakni 38 orang/siswa.

Penetapan besarnya sampel setiap jurusan dilakukan secara proporsional. Lebih jelasnya dapat dilihat pada tabel 3 berikut ini.

Tabel 3. Sampel Penelitian

\begin{tabular}{|c|c|c|c|}
\hline No. & Kelas/Jurusan & \multicolumn{2}{|c|}{ Persentase } \\
\hline & X TKJ 1 & $15 \% \times 36$ & 5 \\
\hline & X UPW 1 & $15 \% \times 36$ & 5 \\
\hline & X JB 1 & $15 \% \times 36$ & 5 \\
\hline & X TGB & $15 \% \times 36$ & 5 \\
\hline & X PM 1 & $15 \% \times 35$ & 5 \\
\hline & X AP 1 & $15 \% \times 37$ & 6 \\
\hline & X AK 1 & $15 \% \times 37$ & 6 \\
\hline & Jumlah & 253 & $\begin{array}{r}37 \\
+1\end{array}$ \\
\hline
\end{tabular}

Sumber: Populasi setelah diolah, 2016

Pemilihan sampel terpilih setiap jurusan dilakukan dengan teknik undian.

\section{Instrumen Penelitian}


Instrumen penelitian yang akan digunakan adalah angket, yang berisi sejumlah pernyataan tertulis yang akan digunakan untuk memperoleh informasi dari responden tentang sikap siswa pada pelajaran kewirausahaan.

Angket tertutup ini disajikan dalam bentuk skala likert dengan lima alternatif jawaban, sehingga responden tinggal memberi tanda check $(\sqrt{ })$ pada jawaban yang tersedia. Skala ini disusun dalam bentuk suatu pernyataan dan diikuti oleh pilihan responden yang menunjukkan tingkatan. Jenis pernyataan ada dua macam yaitu pernyataan positif (favorable) dan pernyataan negatif (unfavorable).

Tabel 4. Alternatif jawaban menurut Skala Likert

\begin{tabular}{lcc}
\hline \multirow{2}{*}{ Alternatif Jawaban } & \multicolumn{2}{c}{ Skor untuk pernyataan } \\
\cline { 2 - 3 } & Positif & Negatif \\
\hline Setuju/selalu/sangat positif & 5 & 1 \\
Setuju/sering/positif & 4 & 2 \\
Ragu-ragu/kadang-kadang/netral & 3 & 3 \\
Tidak setuju/hampir tidak pernah/ negative & 2 & 4 \\
Sangat tidak setuju/tidak pernah & 1 & 5 \\
\hline
\end{tabular}

Sumber : Sugiyono, 2012:136

Lebih lanjut, mengingat bahwa data pada tabel 4 adalah jenis data ordinal, sedangkan asumsi-asumsi model regresi menurut Suwarno dalam Riduwan (2007:4) adalah terpusat pada : “(1) Data yang dianalisis adalah jenis data interval dan ratio; (2) data yang dipilih secara acak (random); (3) data yang dihubungkan berdistribusi normal; (4) data yang dihubungkan berpola linier; (5) dan data yang dihubungkan mempunyai pasangan yang sama sesuai dengan subjek yang sama”. Oleh karena itu data ordinal tersebut harus dikonversi (diubah) ke dalam jenis data interval.

Mentransformasi data ordinal menjadi data interval gunanya untuk memenuhi sebagian dari syarat analisi parametrik yang mana data setidak-tidaknya berskala interval. Tekhnik transformasi yang paling sederhana dengan menggunakan MSI (Method of Successive Interval). Dan menurut Suwarno dalam Riduwan (2007:30) " Langkah-langkah transformasi data ordinal ke interval adalah sebagai berikut " : 
1) Pertama dengan memperhatikan setiap butir jawaban responden dari angket yang disebarkan;

2) Pada setiap butir ditentukan beberapa orang yang mendapat skor 1, 2, 3, 4, dan 5 yang disebut sebagi frekuensi;

3) Setiap frekuensi dibagi menjadi banyaknya responden dan hasilnya disebut proporsi;

4) Menentukan nilai proforsi kumulatif dengan jalan menjumlahkan nilai proporsi secara berurutan perkolom skor;

5) Menggunakan Tabel Distribusi Normal, hitung nilai $Z$ untuk setiap proforsi kumulatif yang diperoleh;

6) Menentukan nilai tinggi identitas untuk setiap nilai $\mathrm{Z}$ yang diperoleh (dengan menggunakan tabel Tinggi Densitas);

7) Menentukan niali skala dengan menggunakan rumus :

$$
N S=\frac{\text { (Density at Lower Limit) }- \text { (Density at Upper Limit) }}{\text { (Area Below Upper Limit) - (Area Below Lower Limit) }}
$$

8) Menentukan nilai skala transformasi (skala akhir) dengan rumus :

$$
\mathrm{Y}=N S+\left[1+\left|N S_{\min }\right|\right]
$$

\section{E. Teknik Pengumpulan Data}

Teknik pengumpulan data yang digunakan dalam penelitian ini adalah:

1. Observasi, yaitu teknik pengumpulan data dengan mengamati secara langsung objek yang akan diteliti. Adapun teknik ini yang akan diteliti yaitu kegiatan belajar siswa, keadaan lingkungan sekolah, mencatat jumlah siswa dalam kelas, dan sebagainya.

2. Angket (kuesioner), dalam penelitian ini terdiri dari butir-butir pernyataan yang dipergunakan untuk mengumpulkan data mengenai sikap siswa pada pelajaran kewirausahaan dan hasil belajar kewirausahaan siswa.

3. Dokumentasi dalam penelitian ini dokumentasi akan digunakan untuk memperoleh nilai ulangan harian siswa yang terpilih sebagai responden dalam penelitian ini. 
4. Wawancara digunakan untuk mendapatkan informasi atau keterangan secara langsung dari guru mata pelajaran kewirausahaan untuk mengetahui hal-hal yang berhubungan dengan kegiatan belajar mengajar kewirausahaan.

\section{F. Uji Validitas dan Reliabilitas Penelitian}

Keabsahan (validitas) hasil penelitian ditentukan oleh alat pengukuran (instrument) yang digunakan dan data yang diperoleh. Jika alat pengukuran variabel tersebut tidak reliabel dan tidak absah, maka hasilnya tidak menggambarkan keadaan yang sesungguhnya. Untuk dapat diyakinkan bahwa data tersebut valid dan handal maka perlu dilakukan dua pengujian yaitu validitas dan reliabilitas.

1. Validitas adalah suatu ukuran yang menunjukkan tingkatan-tingkatan kevalidan atau kesahihan suatu instrument (Suprananto,2012:75). Uji validitas digunakan untuk mengetahui kelayakan butir-butir dalam suatu daftar pertanyaan dalam mendefenisikan suatu variabel. Instrumen dikatakan valid jika instrument sudah mampu mengukur apa yang diinginkan dan mengungkapkan data yang diteliti secara tepat. Hasil $r$ hitung dibandingkan dengan $r$ tabel dimana df $=n-2$ dengan taraf sig 5\%. Dimana kriteria pengujiannya adalah jika $r$ tab $\leq r$ hitung maka butir soal dianggap valid.

2. Reliabilitas adalah suatu instrument yang cukup dipercaya untuk digunakan sebagai alat pengumpul data karena instrument itu sudah baik (Suprananto, 2012:82). Uji reliabilitas dilakukan secara bersama-sama terhadap seluruh butir pertayaan. Jika nilai Alpha > 0,60 maka dianggap reliabel.

\section{G. Teknik Analisis Data}

Teknik analisis data adalah suatu alat yang digunakan untuk menjawab permasalahan dan hipotesis yang diajukan. Untuk mengetahui pengaruh sikap siswa pada pelajaran kewirausahaan terhadap hasil belajar kewirausahaan siswa kelas X di SMK Negeri 4 Makassar. Maka peneliti menggunakan teknik analisis data sebagai berikut: 
1. Deskriptif presentatif digunakan untuk memberikan gambaran atau pembahasan dalam penelitian ini. Adapun langkah-langkah yang ditempuh dalam menggunakan teknik analisis ini, yaitu:

a) Membuat tabel distribusi jawaban angket $\mathrm{X}$ dan $\mathrm{Y}$.

b) Menentukan skor jawaban responden dengan ketentuan skor yang telah ditetapkan.

c) Menjumlahkan skor yang diperoleh dari tiap-tiap responden.

d) Dari jumlah perolehan skor tersebut, selanjutnya dihitung dengan menggunakan rumus persentase yang dikemukakan oleh Sudjana (2004:74) sebagai berikut:

$$
P=\frac{F}{N} \times 100 \%
$$

Dimana : $\quad \mathrm{P}=$ Presentase $(\%)$

$\mathrm{F}=$ Frekuensi

$\mathrm{N}$ = Jumlah responden (sampel)

Selanjutnya Untuk lebih memudahkan mendeskripsikan data kuantitatif pada tiap-tiap hasil belajar kewirausahaan yang diperoleh siswa pada ulangan harian. Digunakan Pengkategorian skor hasil belajar sesuai dengan pedoman yang ditetapkan oleh Departemen Pendidikan Nasional (DEPDIKNAS, 2006) sebagaimana yang tertera pada tabel dibawah ini:

Tabel 5. Kategorisasi hasil belajar kewirausahaan

\begin{tabular}{cc}
\hline Skor & Kategori \\
\hline $85-100$ & Sangat tinggi \\
$75-84$ & Tinggi \\
$55-74$ & Sedang \\
$35-54$ & Rendah \\
$0-34$ & Sangat rendah \\
\hline
\end{tabular}

Sumber : Departemen Pendidikan Nasional (DEPDIKNAS,2006) 
2. Teknik statistik inferensial digunakan untuk mengkaji hipotesis penelitian. Untuk keperluan tersebut dalam mencari pengaruh variabel bebas terhadap variabel terikat yang dianalisis dengan menggunakan analisis regresi linier sederhana dengan taraf signifikan $(\alpha=0,05)$, koefisien determinasi, dan uji parsial (uji t).

a) Analisis regresi linier sederhana bertujuan untuk meramalkan nilai pengaruh satu variabel bebas terhadap satu variabel terikat dengan menggunakan persamaan regresi sebagai berikut :

$$
\hat{\mathbf{Y}}=\mathbf{a}+\mathbf{b X}
$$

Dimana :

$$
\begin{aligned}
\hat{\mathrm{Y}} & =\text { Hasil belajar kewirausahaan } \\
\mathrm{X} & =\text { Sikap siswa } \\
\mathrm{a} & =\text { Konstanta } \\
\mathrm{b} & =\text { Koefisien Arah Regresi }
\end{aligned}
$$

b) Uji parsial (uji t) digunakan untuk menguji signifikansi koefisien regresi maupun korelasi parsial atau hubungan masing-masing variabel bebas dengan variabel terikat. Data dianalisis dengan bantuan computer SPSS versi 20 for windows. Dasar pengambilan keputusan berdasarkan angka probabilitas. Jika angka probabilitas hasil analisis $\leq 0,05$ maka $\mathrm{H}_{0}$ ditolak dan $\mathrm{H}_{1}$ diterima. Apabila $\mathrm{H}_{1}$ diterima menunjukkan ada pengaruh yang signifikan antara variabel bebas terhadap variabel terikat secara parsial.

c) Koefisien determinan $\left(\mathrm{R}^{2}\right)$ berfungsi untuk mengetahui signifikansi variabel koefisien determinan menunjukkan besarnya kontribusi variabel bebas (X) terhadap variabel terikat (Y). Semakin besar nilai determinasi maka semakin baik kemampuan variabel bebas menerangkan variabel terikat. Jika koefisien determinasi $\left(\mathrm{R}^{2}\right)$ semakin besar (mendekati satu) maka dapat dikatakan bahwa pengaruh variabel bebas adalah besar terhadap variabel terikat. Hal ini berarti model yang digunakan semakin kuat untuk menerangkan pengaruh variabel bebas yang diteliti terhadap variabel terikat. Sebaliknya jika determinasi $\left(\mathrm{R}^{2}\right)$ semakin kecil (mendekati nol) maka dapat dikatakan bahwa pengaruh variabel bebas terhadap variabel terikat semakin kecil. Hal ini berarti model yang 
ISSN; 2528-0317 Tasharruf : Journal Economic Vol. 2 No. 2 Desember 2017 and Business Of Islam

digunakan tidak kuat untuk menerangkan variabel bebas terhadap variabel terikat.

\section{HASIL PENELITIAN}

\section{Hasil Uji Validitas dan Reliabilitas Penelitian}

Dalam penelitian ini terdapat 30 butir pertanyaan untuk variabel Sikap siswa pada pelajaran kewirausahaan (X) dan 26 butir pertanyaan untuk variabel hasil belajar siswa (Y). Dalam penelitian ini, butir-butir pertanyaan sudah divalidasi dan direliabilitaskan, dan hasilnya untuk semua butir pertanyaan valid dan reliable.

Tabel 6. Hasil Validasi dan Reliabilitas Variabel Sikap Siswa (X)

Case Processing Summary

\begin{tabular}{|rr|r|r|}
\hline & & $\mathrm{N}$ & $\%$ \\
\hline Cases & Valid & 38 & 100.0 \\
& Excluded $^{\mathrm{a}}$ & 0 & .0 \\
& Total $^{2}$ & 38 & 100.0 \\
\hline
\end{tabular}

a. Listwise deletion based on all variables in the procedure.

\begin{tabular}{|r|r|}
\hline \multicolumn{2}{|c|}{ Reliability Statistics } \\
\hline Cronbach's Alpha & N of Items \\
\hline .544 & 30 \\
\hline
\end{tabular}

Item-Total Statistics

\begin{tabular}{|c|c|c|c|c|}
\hline & $\begin{array}{l}\text { Scale Mean if } \\
\text { Item Deleted }\end{array}$ & $\begin{array}{c}\text { Scale Variance if } \\
\text { Item Deleted }\end{array}$ & $\begin{array}{l}\text { Corrected Item- } \\
\text { Total Correlation }\end{array}$ & $\begin{array}{c}\text { Cronbach's Alpha if } \\
\text { Item Deleted }\end{array}$ \\
\hline pertanyaan 1 & 91.58 & 27.872 & .306 & .522 \\
\hline pertanyaan 2 & 92.11 & 27.394 & .235 & .523 \\
\hline pertanyaan 3 & 90.92 & 29.967 & -.093 & .559 \\
\hline pertanyaan 4 & 91.21 & 29.792 & -.065 & .557 \\
\hline pertanyaan 5 & 91.76 & 28.186 & .164 & .533 \\
\hline pertanyaan 6 & 90.82 & 30.857 & -.288 & .569 \\
\hline pertanyaan 7 & 91.37 & 27.698 & .267 & .522 \\
\hline pertanyaan 8 & 92.13 & 28.063 & .089 & .546 \\
\hline pertanyaan 9] & 90.74 & 29.280 & .083 & .542 \\
\hline pertanyaan 10 & 90.92 & 30.615 & -.204 & .569 \\
\hline pertanyaan 11 & 91.95 & 28.430 & .046 & .553 \\
\hline pertanyaan 12 & 90.68 & 29.249 & .129 & .540 \\
\hline pertanyaan 13 & 90.68 & 30.384 & -.250 & .558 \\
\hline
\end{tabular}


ISSN; 2528-0317 Tasharruf : Journal Economic Vol. 2 No. 2 Desember 2017 and Business Of Islam

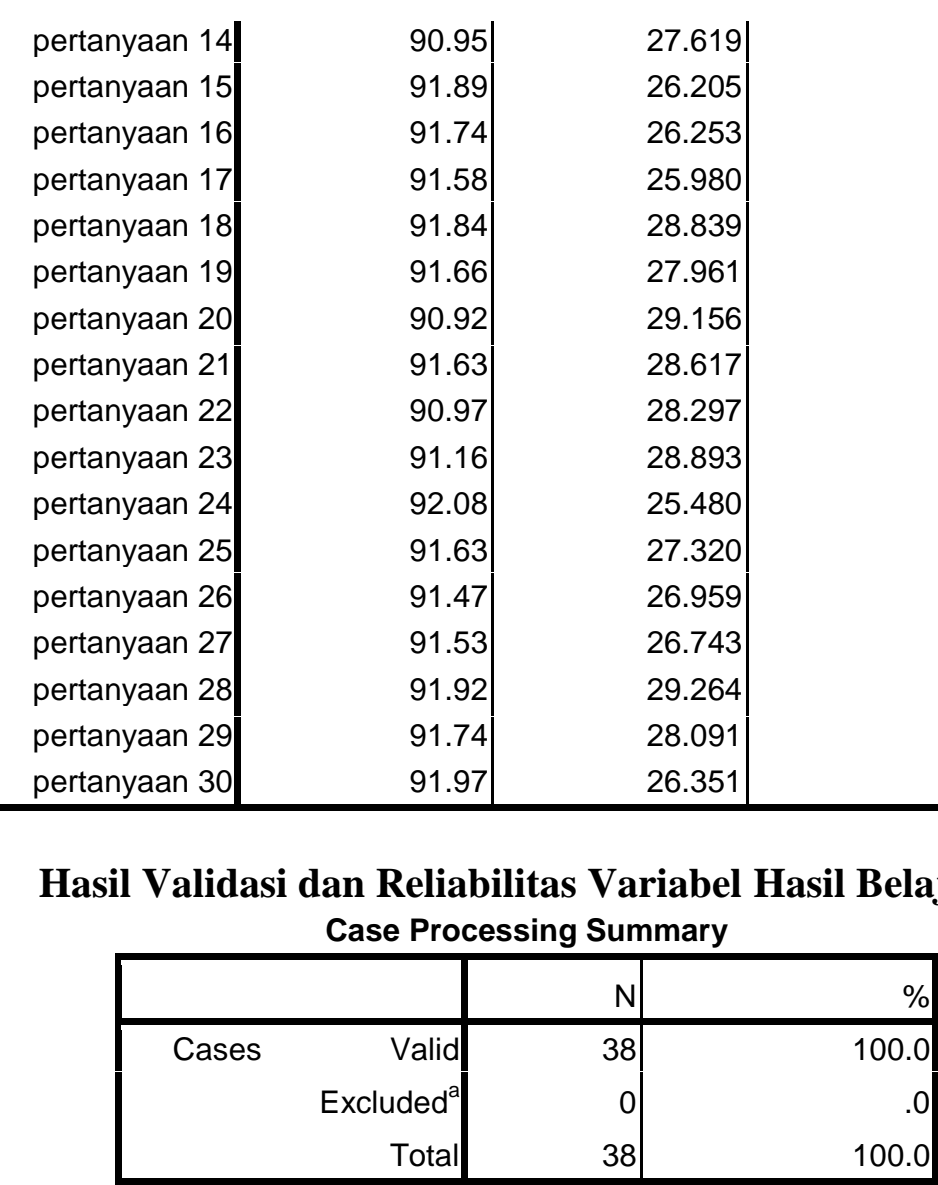

a. Listwise deletion based on all variables in the procedure

Reliability Statistics

\begin{tabular}{|r|r|}
\hline $\begin{array}{r}\text { Cronbach's } \\
\text { Alpha }\end{array}$ & N of Items \\
\hline .665 & 26 \\
\hline
\end{tabular}

Item-Total Statistics

\begin{tabular}{|r|r|r|r|r|}
\hline & $\begin{array}{c}\text { Scale Mean if } \\
\text { Item Deleted }\end{array}$ & $\begin{array}{c}\text { Scale Variance if } \\
\text { Item Deleted }\end{array}$ & $\begin{array}{c}\text { Corrected Item- } \\
\text { Total Correlation }\end{array}$ & $\begin{array}{c}\text { Cronbach's Alpha if } \\
\text { Item Deleted }\end{array}$ \\
\hline pertanyaan 1 & 72.84 & 41.650 & .400 & .643 \\
pertanyaan 2 & 72.89 & 43.232 & .295 & .653 \\
pertanyaan 3 & 73.32 & 40.925 & .362 & .642 \\
pertanyaan 4 & 72.87 & 43.523 & .216 & .657 \\
pertanyaan 5 & 73.37 & 45.374 & -.053 & .679 \\
pertanyaan 6 & 72.95 & 42.105 & .357 & .646 \\
pertanyaan 7 & 72.89 & 43.502 & .197 & .658 \\
pertanyaan 8 & 74.21 & 41.792 & .248 & .653 \\
\hline
\end{tabular}


ISSN; 2528-0317 Tasharruf : Journal Economic Vol. 2 No. 2 Desember 2017 and Business Of Islam

\begin{tabular}{|c|c|c|c|c|}
\hline pertanyaan 9| & 73.53 & $40.797 \mid$ & .356 & .642 \\
\hline pertanyaan 10 & 73.97 & 42.675 & .114 & .670 \\
\hline pertanyaan 11 & 73.21 & 41.306 & .367 & .643 \\
\hline pertanyaan 12 & 73.74 & 43.821 & .067 & .671 \\
\hline pertanyaan 13 & 73.39 & 39.272 & .456 & .630 \\
\hline pertanyaan 14 & 72.97 & 42.999 & .308 & .652 \\
\hline pertanyaan 15 & 73.47 & 39.553 & .429 & .633 \\
\hline pertanyaan 16 & 73.68 & 44.006 & .058 & .672 \\
\hline pertanyaan 17 & 73.95 & 43.727 & .125 & .664 \\
\hline pertanyaan 18 & 74.08 & 44.885 & .317 & .678 \\
\hline pertanyaan 19 & 72.76 & 40.942 & .398 & .640 \\
\hline pertanyaan 20 & 72.82 & 42.317 & .346 & .648 \\
\hline pertanyaan 21 & 73.74 & 46.199 & .532 & .689 \\
\hline pertanyaan 22 & 73.63 & 40.293 & .280 & .650 \\
\hline pertanyaan 23 & 72.82 & 43.235 & .517 & .667 \\
\hline pertanyaan 24 & 73.11 & 44.908 & .402 & .673 \\
\hline pertanyaan 25 & 73.84 & 41.001 & .316 & .646 \\
\hline pertanyaan 26 & 73.18 & 41.938 & .311 & .648 \\
\hline
\end{tabular}

Sumber: Hasil Olahan Data, 2016

\section{Analisis Deskriptif}

Setelah data telah dikumpulkan melalui instrument data yang digunakan yaitu angket yang telah disebarkan kepada 38 orang siswa SMK Negeri 4 Makassar, maka data tersebut lalu dideskripsikan dan dianalisis untuk mendapatkan suatu kesimpulan. Deskripsi data hasil penelitian ini dimaksudkan untuk mengetahui bagaimana kondisi dari sikap dan hasil belajar siswa, dimana peneliti mengungkapnya dengan menelaah berdasarkan tiap butir pertanyaan untuk mengetahui frekuensi alternatif jawaban sehingga peneliti dapat mengungkapnya lebih teliti. Adapun gambaran tentang sikap siswa SMK Negeri 4 Makassar dapat dilihat dari analisis deskriptif di bawah ini:

\section{1) Sikap siswa}

Sikap siswa adalah kesiapan dan kecenderungan siswa untuk bertindak dalam menghadapi suatu obyek atau situasi tertentu akibat hasil dari proses belajar maupun 
pengalaman di lapangan. Dalam penelitian ini, sikap siswa terdiri dari indikator ketekunan belajar, rajin dalam belajar, kedisiplinan belajar dan tanggung jawab. Untuk lebih jelasnya dapat dilihat pada penjelasan di bawah ini :

\section{a. Ketekunan Belajar}

Menurut indikator ketekunan belajar siswa, dapat dilihat pada bahwa siswa masih kurang dalam kesungguhan mengikuti proses pembelajaran. Sebanyak 47,37 persen siswa mengaku kadang-kadang tidak bersemangat belajar kewirausahaan sampai jam pelajaran berakhir, hal ini dapat disebabkan dari diri siswa itu sendiri yang tidak terlalu suka dengan pelajaran kewirausahaan sehingga siswa cenderung cepat bosan dan tidak antusias mengikuti pelajaran kewirausahaan, tetapi dalam sub indikator tekun dalam mengerjakan tugas, siswa tetap memperhatikan tugas-tugas yang diberikan oleh guru bidang studi kewirausahaan, sebanyak 71,05 persen siswa tetap konsisten menyelesaikan tugas yang diberikan oleh guru sesuai dengan tenggang waktu yang diberikan sekalipun dalam pengerjaannya, 42,11 persen siswa yang mendapat kesulitan dalam menyelesaikan tugas yang diberikan berinisiatif bertanya kepada guru ataupun orangtuanya.

Hal ini menggambarkan bahwa sekalipun siswa terlihat tidak antusias mengikuti pelajaran kewirausahaan di kelas, tetapi untuk mencapai hasil belajar yang baik, siswa tetap berusaha untuk mengerjakan segala tugas yang diberikan.

\section{b) Rajin dalam Belajar}

Berdasarkan hasil olah data angket variabel sikap siswa indikator rajin dalam belajar sub indikator giat belajar untuk mendapatkan hasil belajar yang bagus, sebanyak 78,95 persen siswa sepakat bahwa untuk mencapai hasil belajar yang tinggi merupakan hal utama bagi siswa, walaupun 13,16 persen siswa hanya belajar kewirausahaan hanya ketika ada PR atau ulangan saja. Pentingnya memperoleh hasil belajar yang bagus benar-benar disadari siswa, walaupun dalam realitasnya siswa kadang didera rasa malas untuk belajar apalagi ketika mendapat materi yang mereka tidak senangi atau tidak mereka pahami dengan baik, hal ini sebanyak 47,37 persen siswa mengaku kadang-kadang mengalami hal demikian. 


\section{c) Kedisiplinan Belajar}

Jika dilihat dari sisi disiplin belajar siswa, sub indikator patuh dan taat terhadap kegiatan belajar di sekolah, siswa tergolong disiplin. Hal ini diperkuat bahwa sebanyak 78,95 persen siswa tidak pernah bolos atau tidak masuk kelas saat pelajaran kewirausahaan berlangsung. Hal ini juga dipertegas dari hasil wawancara dengan guru bidang studi kewirausahaan Ibu Sri Ayu Suhra Aras Nopember 2016) bahwa:

Saya rasa kemungkinan untuk bolos pada jam pelajaran itu sangat kecil ini juga karena peran guru BK dan wali kelas yang sering mengontrol absensi siswa setiap hari. Dan apabila jika hal itu terjadi ada siswa yang bolos pada saat jam pelajaran kewirausahaan, saya sebagai guru bidang studi kewirausahaan tentunya melakukan tindakan yang dimulai dari tindakan preventif seperti melakukan pendekatan personal terhadap siswa yang bersangkutan apa alasan mengapa sering bolos. Jika tidak ada perubahan baru dilimpahkan kepada guru BK atau wali kelas untuk ditindak lanjuti.

Akan tetapi pada sub indikator perhatian dalam kegiatan pembelajaran, siswa cenderung acuh atau tidak peduli dengan kegiatan pembelajaran, hal ini terlihat sebanyak 42,10 persen siswa jarang menjawab pertanyaan yang diberikan oleh guru dan ketika ada materi yang belum siswa pahami, hanya sekitar 13,16 persen yang akan bertanya kepada guru jika mengalami hal demikian. Hal ini juga dipertegas dari hasil wawancara dengan guru bidang studi kewirausahaan Ibu Sri Ayu Suhra Aras (Nopember 2016) bahwa:

Ketika ada materi yang belum jelas, memang hanya beberapa siswa yang bertanya. Hanya saja sebelum saya berikan jawaban, saya biasanya mengembalikan pertanyaan itu kepada forum kelas. Apakah ada siswa yang dapat menjawab pertanyaan tersebut. Kalau ada, barulah saya yang akan menjelaskan secara rinci jawaban dari pertanyaan tersebut.

Selain itu, perhatian siswa juga terbagi untuk hal hal yang tidak ada hubungannya dengan pelajaran, seperti 44,74 persen siswa mengaku kadang-kadang mengobrol/bergosip saat guru menjelaskan dan 28,95 persen siswa menggunakan handphone saat guru sedang menerangkan, hal ini tentu sedikit banyak dapat menganggu konsentrasi dan perhatian siswa dalam mengikuti pelajaran. Hal ini juga 
dipertegas dari hasil wawancara dengan guru bidang studi kewirausahaan Ibu Sri Ayu Suhra Aras (Nopember 2016) bahwa:

Ketika materi pelajaran sedang berlangsung, sikap siswa itu bervariasi seperti ada yang memperhatikan adapula yang tidak seperti yang duduk di bagian depan konsentrasi pada pelajaran itu sangat tinggi akan tetapi siswa yang duduk di bagian belakang terkadang konsentrasi pada pelajaran itu kurang seperti ada beberapa siswa yang kedapatan mengobrol.

Walaupun itu, pada sub indikator persiapan belajar, siswa terlihat mempersiapkan dengan baik segala sesuatu untuk memulai pelajaran kewirausahaan, misalnya sebanyak 26,32 persen siswa membaca buku kewirausahaan sebelum pelajaran dimulai.

\section{d) Tanggung Jawab}

Adapun pada indikator tanggung jawab siswa jika dilihat dari sub indikator penyelesaian tugas pada waktunya, siswa tetap merasa memiliki tanggung jawab yang tinggi terhadap mata pelajaran kewirausahaan khususnya pada tugas-tugas yang diberikan oleh guru, sebanyak 65,79 persen siswa berusaha menyelesaikan tugas yang diberikan oleh guru tepat pada waktunya. Hal ini juga dipertegas dari hasil wawancara dengan guru bidang studi kewirausahaan Ibu Sri Ayu Suhra Aras (Nopember 2016) bahwa, "Kebanyakan siswa mengumpulkan tugas dengan tepat waktu bahkan ada beberapa dari mereka yang mengumpulkan tugas sebelum tenggang waktu yang saya berikan".

Akan tetapi, pada realitasnya dalam penyelesaian tugas tersebut siswa masih cenderung melakukan tindakan yang menyimpang seperti 10,53 persen siswa kadangkadang menyontek. Kemudian sebanyak 21,05 persen terkadang siswa membuka catatan pada saat ulangan berlangsung. Ini mencerminkan bahwa siswa melakukan berbagai cara untuk meningkatkan hasil belajarnya sekalipun dengan melakukan tindakan menyimpang. Selain itu, berdasarkan sub indikator dapat bekerjasama secara kelompok tercermin bahwa siswa cenderung lebih dapat mengembangkan potensi 
yang dimiliki dengan belajar secara berkelompok, pernyataan ini diperkuat dengan hasil olah data primer indikator sikap siswa sebanyak 57,89 persen merasa belajar kewirausahaan dengan berdiskusi kelompok membuat siswa lebih mudah berpikir dan memahami pelajaran kewirausahaan.

Berdasarkan penjabaran aspek sikap siswa diatas, dapat disimpulkan bahwa sikap siswa dalam mengikuti pelajaran kewirausahaan masih kurang antusias, ini dapat dilihat dari masih adanya siswa yang mengobrol/bergosip dan bermain handphone saat guru sedang menjelaskan materi, ini menunjukkan siswa bersikap acuh terhadap mata pelajaran kewirausahaan, meskipun tidak dipungkiri siswa itu sendiri mengharapkan hasil belajar yang tinggi. Keinginan untuk memperoleh hasil belajar yang tinggi itu pun ditempuh oleh siswa dengan berbagai cara bahkan dengan cara yang negatif sekalipun seperti mencontek dan membuka catatan pada saat ulangan berlangsung. Hal ini semakin menguatkan asumsi bahwa sikap belajar siswa masih terbilang rendah.

\section{2) Hasil Belajar}

Setiap orang yang melakukan kegiatan tentu akan memperoleh hasil. Demikian dengan kegiatan belajar di sekolah, tentu akan memperoleh hasil yang berupa hasil belajar. Hasil belajar merupakan kemampuan-kemampuan yang dimiliki siswa setelah ia menerima pengalaman belajarnya. Hasil belajar dapat dicapai melalui proses belajar, baik tidaknya hasil belajar yang dicapai seseorang tergantung pada proses belajar itu sendiri. Dalam penelitian ini, hasil belajar siswa terdiri dari beberapa aspek yakni kognitif, afektif dan psikomotor yaitu:

\section{a) Kognitif}

Berdasarkan hasil belajar kognitif dapat dilihat bahwa kemampuan siswa untuk menjawab pernyataan sesuai dengan materi seputar kewirausahaan makro dan kewirausahaan mikro sudah baik. Asumsi ini diperkuat oleh hasil olah data primer pada aspek kognitif yang terdiri dari kemampuan siswa dalam membandingkan, menyebutkan, menjelaskan, mendefinisikan dengan lisan sendiri, memberikan contoh serta kemampuan menguraikan, siswa terlihat sudah paham mengenai materi 
kewirausahaan yang diberikan. Contohnya pada sub indikator pengamatan mengenai perbedaan kewirausahaan makro dan kewirausahaan mikro sebanyak 52,63 persen siswa menjawab sangat setuju yang berarti menganggap pernyataan yang diberikan oleh peneliti sudah benar. Ini menandakan secara umum siswa sudah paham mengenai perbedaan kewirausahaan makro dan kewirausahaan mikro. sekalipun sebagian besar siswa sudah mengerti dan menjawab dengan betul pernyataan yang diberikan, akan tetapi ketika diberikan pernyataan yang bersifat mengecoh, siswa masih terlihat kebingungan. Hal ini dibuktikan sebanyak 42,10 persen siswa setuju jika permintaan dan penawaran, perilaku konsumen, perilaku produsen, dan pasar adalah ruang lingkup kewirausahaan makro.

\section{b) Afektif}

Dari segi Afektif, yang terdiri dari penerimaan, sambutan dan apresiasi. Berdasarkan hasil olah data primer sebanyak 44,74 persen siswa mampu menerima pelajaran dengan baik akan tetapi tidak terlalu tertarik untuk mempelajari kewirausahaan secara mendalam, hal ini sebanyak 47,37 persen siswa menjawab tidak setuju. Di lain sisi, berdasarkan hasil pengolahan data, siswa cenderung masih memiliki ego yang tinggi, dapat dilihat pada jawaban responden sebanyak 42,10 persen siswa mengaku sangat sulit menerima pendapat teman dalam berdiskusi. Sementara itu, meskipun 50 persen siswa tidak memanfaatkan waktu luang di sekolah untuk belajar kewirausahaan, akan tetapi 39,47 persen siswa percaya bahwa materi kewirausahaan yang diajarkan oleh guru memiliki manfaat yang penting di masa akan datang, hal ini dapat dilihat dari jawaban responden sebanyak 28,95 persen siswa tidak merasa bahwa pelajaran kewirausahaan adalah pelajaran yang membosankan.

\section{c) Psikomotor}

Dari segi psikomotor yang terdiri dari keterampilan bergerak dan bertindak, kecakapan ekspresi verbal dan non verbal, dan membuat mimik dan gerakan jasmani, Berdasarkan hasil olah data primer menunjukkan siswa sudah mampu mengaplikasikan ilmu yang diperoleh di sekolah ke dalam kehidupan sehari-hari. Hal ini dapat dilihat dari jawaban responden mengenai perilaku konsumen dalam 
kehidupan sehari-hari yang terdiri dari kebiasaan menabung sejak dini, ketelitian dalam membeli produk yang akan digunakan, serta melakukan penawaran dengan penjual sebelum melakukan transaksi jualbeli, sebagian besar siswa menjawab setuju. Akan tetapi usia yang belum matang tetap memberikan dampak atau pengaruh terhadap keinginan siswa dalam melakukan transaksi kewirausahaan, sebanyak 39,47 persen siswa mengaku membeli barang sesuai dengan kebutuhannya, sedangkan 34,21 persen siswa mengaku tidak demikian, yang berarti siswa masih membeli barang sesuai dengan keinginannya saja.

Berdasarkan penjabaran ketiga aspek penilaian hasil belajar tersebut di atas, dapat ditarik kesimpulan bahwa secara keilmuan, siswa dianggap sudah menguasai beberapa materi penting mengenai kewirausahaan makro dan mikro, sekalipun siswa masih terlihat kebingungan menjawab pertanyaan yang bersifat mengecoh. Hasil belajar yang lebih tinggi lagi dapat dicapai siswa apabila dibarengi dengan kecintaan yang lebih dalam lagi kepada bidang studi kewirausahaan. Dimana siswa tidak lagi menganggap pelajaran kewirausahaan sebagai pelajaran yang membosankan melainkan pelajaran yang menyenangkan.

\section{Pengkategorisasian Hasil Belajar}

Adapun nilai ulangan harian yang diperoleh siswa pada pokok bahasan kewirausahaan makro dan mikro yang diberikan oleh guru bidang studi kewirausahaan. Jika dimasukkan ke dalam pengkategorisasian, maka hasil belajar siswa dalam hal ini nilai ulangan harian berada pada kategori tinggi. Untuk lebih jelasnya dapat dilihat ada tabel di bawah ini:

Tabel 6 Hasil Penelitian Pengkategorian Hasil Belajar

\begin{tabular}{ccccc}
\hline No & Skor & Kriteria & Jumlah & Persen \% \\
\hline 1 & $0-34$ & Sangat Rendah & 0 & 0 \\
2 & $35-54$ & Rendah & 0 & 0 \\
3 & $55-74$ & Sedang & 10 & 26,31 \\
4 & $75-84$ & Tinggi & 23 & 60,53 \\
5 & $85-100$ & Sangat Tinggi & 5 & 13,16 \\
\hline
\end{tabular}




\begin{tabular}{rrr}
\hline Jumlah & 38 & 100 \\
\hline
\end{tabular}

Sumber: Hasil Olahan Data, 2016

Berdasarkan tabel hasil belajar kewirausahaan siswa diatas, dapat diketahui bahwa pada umumnya hasil belajar siswa berada pada kategori "tinggi" dengan persentase sebesar 60,53 persen dengan frekuensi 23 orang responden dari 38 orang responden.

\section{PEMBAHASAN}

Dalam penelitian ini diduga variabel sikap siswa pada pelajaran kewirausahaan berpengaruh parsial terhadap hasil belajar kewirausahaan siswa SMK Negeri 4 Makassar. Untuk itu, teknik analisis data yang digunakan dalam penelitian ini adalah analisis deskriptif dan analisis regresi linier sederhana. Secara matematis analisis regresi linier sederhana dapat ditulis dalam bentuk persamaan sebagai berikut:

$$
\hat{\mathbf{Y}}=\mathbf{a}+\mathbf{b X}
$$

Dalam penelitian ini, taraf signifikansi yang digunakan yaitu $0,05 \%$. Taraf signifikansi merupakan taraf kepercayaan. Taraf signifikan $0,05 \%$ artinya taraf kepercayaan atau taraf kebenarannya sebesar 95 persen dengan tingkat kesalahan 5 persen.

\section{Uji-T (Uji Parsial)}

Uji ini dimaksudkan untuk mengetahui bagaimana pengaruh sendiri-sendiri (parsial) dari variabel sikap siswa (X) terhadap hasil belajar kewirausahaan (Y) di SMK Negeri 4 Makassar. Uji t (Uji Parsial) dilakukan dengan hipotesis sebagai berikut:

a. $\mathrm{H}_{0}: \mathrm{b}_{1}=0$

Artinya tidak terdapat penagruh yang signifikan antara variabel sikap siswa $(\mathrm{X})$ terhadap variabel hasil belajar kewirausahaan (Y).

b. $\mathrm{H}_{1}: \mathrm{b}_{1} \neq 0$ 
Artinya terdapat pengaruh yang signifikan antara variabel sikap siswa (X) terhadap variabel hasil belajar kewirausahaan (Y).

c. diperoleh dengan derajat bebas $=\mathrm{n}-\mathrm{k}$.

$\mathrm{n}=$ jumlah sampel yaitu 38 siswa;

$\mathrm{k}=$ jumlah variabel yang digunakan $(\mathrm{k}=2)$. Maka variabel derajat bebas $=38-2=36$. Taraf signifikan yang digunakan yaitu $0,05 \%$, Maka sig 0,05 (36) adalah 1,688.

Berikut ini variabel yang mempunyai pengaruh terhadap hasil belajar kewirausahaan yaitu:

Tabel 7 Uji T, Pengaruh secara Parsial Variabel Sikap siswa (X) terhadap Hasil belajar kewirausahaan (Y)

\begin{tabular}{ccccccc}
\hline \multirow{2}{*}{ Model } & \multicolumn{2}{c}{$\begin{array}{c}\text { Unstandardized } \\
\text { Coefficients }\end{array}$} & $\begin{array}{c}\text { Standardized } \\
\text { Coefficients }\end{array}$ & T & Sig. \\
\cline { 2 - 4 } & $\mathbf{B}$ & Std. Error & & & \\
\hline (Constant) & 65.591 & 17.628 & & 3.948 & .000 \\
Sikap siswa & .271 & .175 & .367 & .405 & .688 \\
\hline
\end{tabular}

a.Dependent Variable: Hasil Belajar

Sumber : Hasil Pengolahan Data 2016

Berdasarkan tabel 7, menunjukkan bahwa variabel sikap siswa memiliki tingkat signifikan yang lebih besar dari $\alpha$ : 0,05, maka dapat disimpulkan tidak ada pengaruh signifikan terhadap hasil belajar (Y). Adapun model regresi yang digunakan adalah model regresi linier sederhana dengan satu variabel bebas dan satu variabel terikat dengan persamaan regresi sebagi berikut :

$$
\hat{\mathbf{Y}}=\mathbf{6 5 . 5 9 1}+\mathbf{0 , 2 7 1} \mathrm{X}
$$

Dengan memperhatikan parameter Beta $(\beta)$, maka dapat dianalisis mengenai pengaruh variabel Sikap siswa $(\mathrm{X})$ terhadap variabel Hasil belajar kewirausahaan siswa (Y) yaitu: dari hasil regresi diperoleh sig 0,688>0,05 maka $\mathrm{H}_{0}$ diterima. Artinya, sikap siswa tidak berpengaruh signifikan terhadap hasil belajar kewirausahaan siswa, akan tetapi memiliki kecenderungan untuk berpengaruh positif. 
Dengan regresi $\mathrm{B}=0,271$ yang bertanda positif menunjukkan bahwa apabila sikap siswa ditingkatkan secara optimal sampai 100\%, maka hasil belajar siswa akan meningkat pula sebesar 27,1 persen.

Selain itu diperoleh $\mathrm{T}_{\text {hitung }}$ sebesar 0,405 sedangkan $\mathrm{T}_{\text {tabel }}$ pada taraf signifikan $\alpha=0,05$, maka diperoleh $\mathrm{T}_{\text {tabel }}$ sebesar 1,688. Hal ini menunjukkan $\mathrm{T}_{\text {tabel }}$ lebih besar daripada $\mathrm{T}_{\text {hitung }}$ yaitu $0,405<1,688$. Sehingga $\mathrm{H}_{1}$ ditolak dan $\mathrm{H}_{0}$ diterima yang artinya tidak terdapat pengaruh yang signifikan antara variabel sikap siswa terhadap hasil belajar kewirausahaan siswa.

\section{Koefisien Determinasi $\left(\mathbf{R}^{2}\right)$}

Analisis $R^{2}$ (R Square) atau koefisien determinasi digunakan untuk mengetahui seberapa besar persentase sumbangan pengaruh variabel independen terhadap variabel dependen.

Tabel 8 R Square $\left(\mathrm{r}^{2}\right)$, Besarnya Pengaruh Sikap siswa $(\mathrm{X})$ terhadap Peningkatan Hasil belajar kewirausahaan (Y)

\begin{tabular}{clccr}
\hline Mo & R & R Squa & $\begin{array}{c}\text { Adjusted } \\
\text { Square }\end{array}$ & $\begin{array}{c}\text { Srd. Error } \\
\text { the Estimate }\end{array}$ \\
\hline 1 & $.367^{\mathrm{a}}$ & .085 & .0 & $5.611^{\prime}$ \\
\hline
\end{tabular}

a. Predictors: (Constant), sikap siswa

Sumber : Hasil Pengolahan Data 2016

Berdasarkan tabel 8 , nilai koefisien determinasi $\left(\mathrm{R}^{2}\right)$ adalah 0,085 . Hal tersebut berarti memberikan indikasi bahwa kontribusi variabel sikap siswa terhadap hasil belajar kewirausahaan adalah sekitar 8,5 persen. Dengan kata lain, sekitar 8,5 persen hasil belajar kewirausahaan (Y) dipengaruhi oleh sikap siswa. Serta sisanya 91,5 persen hasil belajar kewirausahaan siswa ditentukan oleh faktor-faktor lain yang tidak diperhatikan dalam penelitian ini.

Hasil penelitian yang diperoleh menunjukan bahwa sikap siswa merupakan faktor penentu meningkatnya hasil belajar siswa. Walaupun secara matematis tidak 
memiliki pengaruh yang signifikan. Adanya pengaruh tidak signifikan yang diberikan oleh sikap siswa disebabkan oleh kemungkinan beberapa faktor diantaranya:

1. Hasil olah data angket menunjukkan bahwa sikap siswa dalam mengikuti pelajaran masih kurang antusias, dalam hal ini siswa yang cenderung kurang memperhatikan pada saat guru sedangkan menjelaskan materi, hal ini terlihat dari siswa jarang menjawab pertanyaan yang diberikan oleh guru dan perhatian siswa juga terbagi untuk hal-hal yang tidak ada hubungannya dengan pelajaran. Hal ini tentu saja dapat mengganggu konsentrasi dan perhatian siswa dalam mengikuti pelajaran. Akan tetapi kebanyakan dari mereka memiliki hasil belajar yang baik, Berdasarkan pengolahan data tersebut, sikap siswa tidak begitu mempengaruhi hasil belajar kewirausahaan siswa. Ada banyak faktor lain yang dapat mempengaruhi tinggi rendahnya hasil belajar tidak hanya sikap siswa.

2. Adapun hasil wawancara dengan guru bidang studi kewirausahaan bahwa ada beberapa sikap siswa yang masih kurang. Apalagi ketika materi pelajaran sedang berlangsung, sikap siswa itu bervariasi seperti ada yang memperhatikan adapula yang tidak seperti yang duduk di bagian depan konsentrasi pada pelajaran itu sangat tinggi akan tetapi siswa yang duduk di bagian belakang terkadang konsentrasi pada pelajaran itu kurang seperti ada beberapa siswa yang kedapatan mengobrol. Akan tetapi kebanyakan dari siswa mengumpulkan tugas dengan tepat waktu bahkan ada beberapa dari mereka yang mengumpulkan tugas sebelum tenggang waktu yang diberikan.

Dari beberapa faktor yang menyebabkan tidak adanya pengaruh yang signifikan terhadap hasil belajar kewirausahaan siswa, hal ini sejalan dengan teori Aunurrahman (2008:37) menyatakan bahwa:

Aktivitas belajar siswa banyak ditentukan oleh sikap siswa ketika akan memulai kegiatan belajar. Bilamana ketika akan memulai kegiatan belajar, siswa memiliki sikap menerima (positif) atau ada kesediaan emosional untuk belajar, maka siswa akan cenderung untuk berusaha terlibat dalam kegiatan belajar dengan baik. Namun bila yang muncul adalah sikap menolak (negatif) sebelum belajar atau ketika akan memulai pembelajaran, maka siswa cenderung kurang memperhatikan/mengikuti kegiatan belajar. Sikap siswa ini 
terlihat pada saat mengikuti pelajaran atau sebaliknya bersikap acuh terhadap aktivitas belajar.

\section{KESIMPULAN}

Berdasarkan hasil penelitian dan pengolahan analisis data, maka dapat ditarik kesimpulan bahwa sikap siswa secara parsial berpengaruh positif dan tidak signifikan terhadap hasil belajar kewirausahaan siswa di SMK Negeri 4 Makassar. Pada taraf signifikan $\alpha=0,05$ dengan persamaan regresi $\hat{Y}=65.591+0,271 X$ dan koefisien determinasi $\left(\mathrm{R}^{2}\right)$ sebesar 0,085 persen yang berarti sekitar 8,5 persen hasil belajar kewirausahaan siswa dipengaruhi oleh sikap siswa, sedangkan sisanya yaitu 91,5 persen dipengaruhi oleh faktor lain yang tidak diperhatikan dalam penelitian ini. Tidak signifikannya variabel sikap siswa $(\mathrm{X})$ terhadap hasil belajar kewirausahaan siswa (Y) dapat disebabkan oleh beberapa faktor, salah satu diantaranya yaitu sikap siswa yang masih kurang antusias dalam mengikuti pelajaran kewirausahaan. Hal ini terlihat dari kurangnya perhatian siswa pada saat kegiatan pembelajaran berlangsung, hal ini disebabkan perhatian siswa terbagi untuk hal-hal yang tidak ada hubungannya dengan pelajaran yang tentunya dapat mengganggu konsentrasi dan perhatian siswa dalam mengikuti pelajaran kewirausahaan.

\section{DAFTAR PUSTAKA}

Abdul, Haling. 2007. Belajar dan Pembelajaran. Makassar: Badan Penerbit UNM

Arikunto, Suharsimi. 2012. Manajemen Penelitian. Jakarta: Rineka Cipta

Aunurrahman. 2008. Belajar dan Pembelajaran. Bandung: Alfabeta.

Depdiknas. 2006. Kurikulum Tingkat Satuan Pendidikan. Jakarta : Depdiknas.

Hasmawaty N. Suparman. 2005. Pengaruh Sikap dan Minat Belajar Terhadap Hasil Belajar Matematika Siswa Kelas X SMA Negeri 3 Makassar. Skripsi. Fakultas 
ISSN; 2528-0317 Tasharruf : Journal Economic Vol. 2 No. 2 Desember 2017 and Business Of Islam

Matematika dan Ilmu Pengetahuan Alam Universitas Negeri Makassar (UNM)

Islamuddin, Haryu. 2011. Psikologi Pendidikan. Yogyakarta : Pustaka Pelajar

Kusaeri dan Suprananto. 2012. Pengukuran dan Penilaian Pendidikan. Yogyakarta: Graha Ilmu

Muhibbinsyah. 2010. Psikologi Pendidikan Dengan Pendekatan Baru. Bandung: Remaja Rasdakarya.

Munarfah, Andi dan Muhammad Hasan. 2009. Metode Penelitian. Jakarta: CV. Praktika Aksara Semesta (PRASSE).

Nana Sudjana, 2010. Penilaian Hasil Belajar Mengajar. Bandung : Remaja Rasdakarya

Riduwan dan Engkos Ahmad Kuncoro. 2007. Cara Menggunakan dan Memaknai Analisi Jalur (Path Analysis). Bandung : Alfabeta

Rizcafitria. 2011. http://Rizcafitria.wordpress.com/2011/04/30/sikap-belajar-peserta didik (diakses tanggal 24 Mei 2016)

Sahabudin, H. 2007. Mengajar dan Belajar. Makassar : Badan Penerbit UNM.

Sardiman, A.M. 2012. Interaksi dan Motivasi Belajar Mengajar. Jakarta : Raja Grafindo Persada

Sarwono, Sarlito. 2009. Pengantar Psikologi Umum. Jakarta: Raja Grafindo Persada

Setiawan. 2008. Teknologi Pengajaran. Bandung : Sinar Baru Algesindo

Sujarweni, V. Wiratna. 2012. SPSS Paramedis. Yogyakarta : Gava Media.

Winda Dewi Puspasari. 2010. Meningkatkan Sikap Positif Siswa SMA Negeri 1 Muntilan Terhadap Matematika Melalui Pembelajaran Berbasis Masalah. Skripsi. Fakultas Matematika dan Ilmu Pengetahuan Alam Universitas Negeri Yogyakarta. (diakses 22 Maret 2016) 